\title{
SUMO COACHES TRAINING
}

Ruslan Khalik ogly Bairamov

Postgraduate Student, Kharkiv State Academy of Physical Culture, Ukraine e-mail: bayramov16031990@ukr.net, orcid.org/0000-0001-8204-5533

\section{Anastasiia Bondar}

$\mathrm{PhD}$, Professor, Kharkiv State Academy of Physical Culture, Ukraine e-mail: anastasiabond1@ukr.net,orcid.org/0000-0002-2816-4985

\section{Iwona Wojnowska}

MA, Polonia University in Czestochowa, Interdisciplinary Faculty, Poland e-mail: iwojnowska@ap.edu.pl,orcid.org/0000-0002-9004-2970

\section{Summary}

The aim of this paper is to study the peculiarities of training sumo coaches. The article discusses the features of training sumo coaches, analyzes the regulatory documents regulating the training, certification and advanced training of coaches, studies the state of staffing in sumo and its dynamics over the past 5 years in Ukraine. It was found that despite the fact that the number of sumo coaches increased by $30 \%$, there remains a shortage of staffing in this sport, since the number of sumo athletes increases annually and there are an average of 20 athletes per coach, while the recommended number of athletes should be from 14 to 6 people, depending on the stage of long-term training of athletes. Therefore, there is an objective need for training sumo coaches in specialized institutions of higher education. The training of sumo coaches is carried out in the framework of educational programs for the training of coaches in martial arts. $75 \%$ of the interviewed applicants for higher education - future coaches in martial arts are satisfied with their chosen profession, which indicates their responsible attitude to the choice of profession and the high quality of education in the institution of higher education where they study.

Keywords: athlete, martial arts, Department, institution of higher education, educational program.

\section{DOI https://doi.org/10.23856/3920}

\section{Introduction}

Every year, sumo is becoming an increasingly popular sport in many countries of the world, the number of athletes is growing, as well as people who want to participate in this sport, respectively, the demand for qualified personnel who are able to provide the training process and competitive activities in sumo is growing. So, the issue of training sumo coaches becomes relevant, unfortunately, it is not sufficiently covered in modern scientific and methodological literature. Konokh A. (2019), Kuznetsova I. (2019) studied some features of the training of coach-instructors from oriental martial arts and their readiness for professional activity in children and youth sports schools, the formation of the professional readiness of future coaches in martial arts using training devices was considered by Zadorozhna O., Briskin Y., Pitin M. (2020), Pavlyuk E. (2013) described the concept of training future trainers-teachers in higher educational institutions, while none of the researchers singled out the peculiarities of training sumo trainers, which determined the choice of the topic our research.

The aim of this paper is to study the peculiarities of training sumo coaches.

Methods and materials of research. In the course of the study, an analysis of literary sources and documents was used, due to which the degree of study of the problem 
in dissertations, scientific articles and publications of modern scientists was determined, based on the analysis of statistical reports in the form 2-fk, the level of staffing in sumo and the change in these indicators over the last 5 years, analysis of regulatory and educational documents, in particular, the standard of higher education in Ukraine: the first (bachelor's) level of higher education, field of knowledge 01 Education / Pedagogy, specialty 017 physical culture and sports and educational and professional programs made it possible to find out the direction, structure and content of the process of preparing a future coach. A survey (questionnaire survey) of future trainers made it possible to determine the level of satisfaction with the chosen profession. Thanks to a systematic analysis, an idea of the training of future sumo coaches was formed, the state and prospects for further improving this process were determined.

\section{Coaches in professional sumo}

In modern sumo there are two areas: professional and amateur. Professional sumo (ozumo) exists only in Japan. The governing body of professional sumo is the Japan Sumo Association (JSA). Amateur sumo is developing in all other countries, for which the International Sumo Federation (ISF) was established in Tokyo (Bairamov, R. \& Bondar, A., 2019). The rules of amateur and professional sumo coincide, in general. However, in professional sumo there are no weight categories, wrestlers are not divided into categories. Women have been taking part in amateur sumo since 2001, but not in professional sumo, in which women are strictly forbidden to perform and engage in wrestling (Sports Committee of Ukraine, 2020). In professional sumo, coaches (oyakata) must obtain a personal license to coach, each with its own name and long history. The number of licenses is historically limited (105 of them), more or less prestigious. The main conditions for obtaining a coaching license are Japanese citizenship and high athletic achievements of the wrestler. The license gives the right to train athletes in a sumo school ("room"), and eventually lead it (Ivanov O., 2004)

\section{Coaches in amateur sumo}

In amateur sumo, athletes are trained by coaches who have a license that is easier to obtain than in professional sumo. A coach is a specialist in some kind of sport who conducts educational and training work aimed at educating and improving the skills of athletes, developing their functional capabilities (Mishchenko, R. F. \& Mishchenko, M. M., 2015). In Ukraine, the right to conduct physical culture, health and sports activities is provided to specialists who have special education and an appropriate educational and qualification level, the state provides training, retraining and advanced training of personnel in the field of physical culture and sports (The Verkhovna Rada of Ukraine, 1994).

Coaches pass compulsory certification in the manner determined by the central executive authority that ensures the formation of state policy in the field of physical culture and sports (The Verkhovna Rada of Ukraine, 1994). Coaches (coach-instructor) who work in physical culture and sports institutions and have passed certification are assigned the following qualification categories for the sport:

- highest category;

- first category;

- second category (The Verkhovna Rada of Ukraine, 2014).

The general requirements for the certification of coaches (coach-instructor) of physical culture and sports institutions to determine their qualification level for the assignment of qualification categories are: 
- higher education in the specialty "Physical culture and sports" and an educational degree "bachelor" or "master";

- fulfillment of effective indicators of the work of trainers (coach-instructor), which are taken into account when assigning qualification categories, in accordance with the Procedure for attestation of trainers (coach-instructor) (The Verkhovna Rada of Ukraine, 2014).

In non-Olympic sports, including sumo, qualification categories are assigned to coaches (coach-instructor) for the effective indicators of athletes provided for by the Procedure for the certification of coaches (coach-instructor), shown in the program numbers, provided that athletes participate in them at least from 10 countries at international sports competitions or 10 regions at all-Ukrainian sports competitions (The Verkhovna Rada of Ukraine, 2014).

\section{Dynamics of sumo development in Ukraine}

Sumo is a popular non-Olympic sport that is developing in 82 countries of the world, including Ukraine (Bairamov, R. \& Bondar, A., 2019). The number of Ukrainian sumo athletes is growing every year and today it is 1239 people, classes with them are conducted by 61 coaches, 30 of whom are full-time coaches, 32 have a special higher education (Ministry of Youth and Sports of Ukraine, 2020). The statistics given in Table 1 show that in the period from 2015 to 2019, the number of sumo athletes increased by 191 people, and coaches by 22 people, of which full-time coaches - by 12 people, the number of coaches with special higher education - by 6 people. Accordingly, the number of sumo athletes increased by $15 \%$, coaches - by $30 \%$, full-time coaches - by $40 \%$, coaches with special higher education - by $19 \%$.

Number of athletes and sumo coaches in Ukraine from 2015 to 2019

\begin{tabular}{|c|c|c|c|c|}
\hline Year & $\begin{array}{c}\text { Number of people } \\
\text { practicing sumo }\end{array}$ & $\begin{array}{c}\text { Number of physical } \\
\text { culture and sports workers } \\
\text { who conduct classes: }\end{array}$ & $\begin{array}{c}\text { of them full-time } \\
\text { coaches }\end{array}$ & $\begin{array}{c}\text { of them with special } \\
\text { higher education }\end{array}$ \\
\hline $\mathbf{2 0 1 5}$ & 1048 & 43 & 18 & 26 \\
\hline $\mathbf{2 0 1 6}$ & 1099 & 42 & 19 & 31 \\
\hline $\mathbf{2 0 1 7}$ & 1029 & 47 & 19 & 31 \\
\hline $\mathbf{2 0 1 8}$ & 1156 & 57 & 26 & 35 \\
\hline $\mathbf{2 0 1 9}$ & 1239 & 61 & 30 & 32 \\
\hline
\end{tabular}

Analysis of the data in Table 1 showed that, as of 2015, there were on average 24 athletes per coach, and in $2019-20$ athletes. Despite the increase in the number of coaches within 5 years by $30 \%$, there remains a shortage of staffing for sumo, because according to the "Norms of filling the groups of departments in non-Olympic sports of complex children and youth sports schools, children and youth sports schools" (Ministry of Youth and Sports of Ukraine, 2017), it is recommended to complete a group of initial training of no more than 14 children, basic training - 10, specialized training -6 , preparation for higher sportsmanship -4 athletes. In sports and recreation camps during the vacation period, under the guidance of one coach-instructor, 15-20 athletes can study in daytime sports and recreation camps and 10 athletes - in round-the-clock (The Cabinet of Ministers of Ukraine, 2019). Therefore, there is an objective need for training sumo coaches. 


\section{Features of training sumo coaches}

Since sumo is an ancient type of oriental martial arts, during the training of coaches, one should take into account the peculiarities of their future activities (Kuznetsova I., 2019), because a trainer in martial arts:

1. must adhere to the appropriate philosophical principles in the training process and in life; to be a role model for young athletes.

2. must have a system of medico-biological, psychophysiological, psychological and pedagogical knowledge in order for students to achieve high sports results and to maintain physical health.

3. must have a detailed understanding of the factors that determine the effectiveness of an athlete's competitive activity, of the relationship between the structure of competitive activity and the structure of readiness.

4. must effectively carry out the process of managing the training process.

5. must control the occurrence, take into account the peculiarities of the course, if necessary - carry out the correction of the psychological states of the athlete.

6. must assess the current and operational milestones of the young athlete.

7. must, in the process of monitoring sports success, evaluate and take into account: a) the effectiveness of the athlete's competitive activity; b) the level of development of physical qualities, technical and tactical skills, mental and integral readiness; c) the capabilities of individual functional systems of the body of a young athlete, ensuring the effectiveness of competitive activity; d) the body's reaction to the proposed training loads, the peculiarities of the process of fatigue and recovery.

8. must ensure the purposeful development of specialized mental processes in a young athlete, which will allow him to realize his physical and technical-tactical capabilities and achieve high sports results.

In the course of the study, it was found that the training of coaches and judges in sumo is carried out within the educational programs for the training of coaches in martial arts at the Kharkov State Academy of Physical Culture at the Department of Martial Arts. The educational process is conducted in accordance with the standard of higher education in Ukraine: the first (bachelor's) level of higher education, field of knowledge 01 Education / Pedagogy, specialty 017 - physical culture and sports. The training of coaches in martial arts provides for a theoreti$\mathrm{cal}$ and practical course and contains mandatory and optional components. During their studies, applicants for higher education acquire integral, general and professional competencies. As part of the educational program at the Department of Martial Arts, students study such disciplines as "Theory of methodology in sports (martial arts)"; "Theory of a systematic approach in the professional activity of a coach"; "Modern technologies for training wrestlers"; "Training of judges (by type of sport)" (Department of Martial Arts, 2019).

A survey of students of the Department of Martial Arts showed that the vast majority (75\%) of future coaches in martial arts are satisfied with the chosen profession, it is characterized by their attitude to school, relationships with teachers and students, working conditions, attitude to students, attitude to leadership. $60 \%$ of applicants for education chose the future profession of a martial arts coach because they like their sport and want to develop it in the future, $20 \%$ went into this profession because their parents are also athletes or coaches, $15 \%-$ because they are active athletes and see the prospect of further employment in this particular profession, $5 \%$ - because they want to train children. Interestingly, $8 \%$ of those surveyed are already training athletes. 


\section{Conclusions}

The study showed that today there is a shortage of staffing in sumo, due to the fact that the number of people who practice sumo increases annually, respectively, the demand for sumo coaches is growing and there is an objective need for their training. Today in Ukraine there is experience in training sumo coaches as part of the educational program for training coaches in martial arts, while a survey of future coaches showed that $75 \%$ of them are satisfied with their chosen profession, which indicates their responsible attitude to the choice of profession and high quality education at the institution of higher education where they study. Further solution of the problem of staffing sumo, in our opinion, will be facilitated by the training of sumo trainers in other regions of our country and the creation of the necessary organizational and managerial conditions for this in higher education institutions, the study of these prospects can become the subject of further scientific research.

\section{References}

Bairamov, R. \& Bondar, A. (2019). Organizational and managerial bases of activity of the Kharkiv Regional Sumo Federation. Slobozhanskyi herald of science and sport., Vol. 7 No. 3(71), 4-8 (DOI: https://doi.org/10.5281/zenodo.3371196)

Department of Martial Arts. (2019). Kharkiv State Academy of Physical Culture.: https://khdafk.kh.ua/kafedra-edinoborstv/ [in Ukrainian]

Ivanov O. (2004). Sumo. Zhyvye traditsyi drevnei Yaponii. [Sumo. living traditions of ancient Japan] Moscow: Style-MG. [in Russian]

Kuznetsova I. (2019). Formuvannia hotovnosti maibutnikh treneriv do podruzhnoho mystetstva do profesiinoi diialnosti $v$ dytiacho-yunatskykh sportyvnykh shkolakh [The formation of readiness of future marital arts trainers for professional activity at children's and young people's sports schools]. (Doctoral PhD dissertation). Kharkiv: Kharkiv National University of Internal Affairs [in Ukrainian]

Ministry of Youth and Sports of Ukraine. (2017). Nakaz vid 10.11.2017 № 4706 Pro vnesennia zmin do nakazu Ministerstva molodi ta sportu Ukrainy vid 17 sichnia 2015 roku № 67 «Pro orhanizatsiiu navchalno-vykhovnoi roboty dytiacho-yunatskykh sportyvnykh shkil» [Of the Order of 10.11.2017 No. 4706 About modification of the order of the Ministry of Youth and Sports of Ukraine of January 17, 2015 No. 67 "On the organization of educational and training work of children's and youth sports schools"]. Kiev. Retrieved from http://search.ligazakon. ua/l_doc2.nsf/link1/RE31551.html [in Ukrainian]

Ministry of Youth and Sports of Ukraine. (2020). Statystyka [Statistics]. Kiev. Retrieved from http://dsmsu.gov.ua/index/ua/category/55 [in Ukrainian]

Praktychnyi posibnyk z orhanizatsii roboty trenera [Practical guide to organizing the work of the coach of CYSS]. (2015). Arrangements: Mishchenko, R.F. \& Mishchenko, M.M. Kiev. [in Ukrainian] Sports Committee of Ukraine. (2020). Federatsiia sumo Ukrainy [Sumo Federation of Ukraine]. Kiev. Retrieved from https://scu.org.ua/type_sport/sumo/ [in Ukrainian]

The Cabinet of Ministers of Ukraine. (2019). Polozhennia pro dytiacho-yunatskykh sportyvnu shkolu [Regulations on children's and youth sports school]. Retrieved from https://zakon.rada. gov.ua/laws/show/993-2008-\%D0\%BF\#Text [in Ukrainian]

The Verkhovna Rada of Ukraine. (1994). Zakon Ukrainy "Pro fizychnu kulturu i sport" [Law of Ukraine "On Physical Culture and Sports"]. Kiev. Retrieved from https://zakon.rada.gov.ual laws/show/3808-12 [in Ukrainian]

The Verkhovna Rada of Ukraine. (2014). Poriadok atestatsii treneriv (treneriv-vykladachiv). [Procedure for attestation of trainers (trainers-teachers)]. Kiev. Retrieved from https://zakon. rada.gov.ua/laws/show/z0180-14 [in Ukrainian] 